\title{
Performance of Parents and Hybrids of Pigeonpea (Cajanus cajan (L.) Millsp.) in terms of Yield and Yield Contributing Characters
}

\author{
J. Srivarsha ${ }^{1,2}$, J. E. Jahagirdar ${ }^{3}$, C. V. Sameer Kumar ${ }^{\text {* }}$, A. J. Hingane ${ }^{1}$, D. K. Patil ${ }^{3}$, \\ V. K. Gite ${ }^{3}$, H. B. Shruthi ${ }^{1}$ and T. M. Bhosle ${ }^{2}$ \\ ${ }^{1}$ International Crops Research Institute for the Semi-Arid Tropics, Patancheru, Telangana \\ ${ }^{2}$ College of Agriculture, Badnapur, VNMKV, Parbhani, Maharashtra \\ ${ }^{3}$ Agricultural Research Station, Badnapur, VNMKV, Parbhani, Maharashtra \\ *Corresponding Author E-mail: c.sameerkumar@cgiar.org \\ Received: 28.09.2017 | Revised: 25.10.2017 | Accepted: 1.11.2017
}

\begin{abstract}
Twelve parents were used in the crossing programme to produce 27 hybrids in $L \times T$ fashion during kharif 2015-16. In the field conditions, parents and hybrids were planted in Randomized Block Design of three replications and evaluated for the performance in terms of yield and yield contributing characters during kharif 2016-17. Observations were recorded on ten characters viz., plant height, days to 50\% flowering, days to maturity, number of primary branches per plant, number of secondary branches per plant, number of pods per plant, number of seeds per pod, 100 seed weight, grain yield per plant and harvest index. It was observed that increase in number of pods per plant directly contributed to increased yield. Among the twenty seven hybrids, ICPA $2039 \times$ ICPL 161, ICPA $2039 \times$ ICPL 90048 and ICPA $2039 \times$ ICPL149 had high grain yield.
\end{abstract}

Key words: Variability, Hybrid, Pigeonpea, Yield, Yield contributing character.

\section{INTRODUCTION}

Pulses are major dietary sources of proteins among the vegetarians in India. Though India is the world's largest producer of pulses, it imports a large amount of pulses to meet the growing domestic needs as it is the largest consumer too. It has been estimated that India's population would reach 1.68 billion by 2030 from the present level of 1.21 billion. Accordingly, the projected pulse requirement for the year 2030 is 32 million tonnes with an anticipated required growth rate of $4.2 \%{ }^{3}$.
Among these protein rich group of crops, pigeonpea [Cajanus cajan (L.) Millsp.] occupy a prominent place among the farmers of Africa, tropics and sub tropics of Asia. In India, pigeonpea is grown in an area of 5.21 million hectares with a production of 4.23 million tonnes ${ }^{1}$. Although India leads the world both in area and production of pigeonpea, its productivity is lower (673 $\mathrm{kg} / \mathrm{ha}$ ) than the world average $(762.4 \mathrm{~kg} / \mathrm{ha})^{2}$.

Cite this article: Srivarsha, J., Jahagirdar, J.E., Kumar, C.V.S., Hingane, A.J., Patil, D.K., Gite, V.K., Shruthi, H.B. and Bhosle, T.M., Performance of Parents and Hybrids of Pigeonpea (Cajanus cajan (L.) Millsp.) in terms of Yield and Yield Contributing Characters, Int. J. Pure App. Biosci. 6(1): 1271-1275 (2018). doi: http://dx.doi.org/10.18782/2320-7051.5803 


\section{Srivarsha et al}

The development of commercial hybrid pigeonpea programme was innovated at ICRISAT in collaboration with ICAR (Indian Council of Agricultural Research). This resulted in the successful development of the first GMS based pigeonpea hybrid, released in 1991 in India ${ }^{6}$. Stagnant production, soaring prices and enhanced imports of pigeonpea made the researchers to focus on increasing pigeonpea productivity. Pigeonpea hybrids play a potential role to achieve quantum jump in pigeonpea productivity ${ }^{8}$. The information about per se performance of genotypes is of utmost importance for crop improvement. The range of mean values aids in presenting a rough estimate about the variation in magnitude of variability present among the genotypes. The characters showing wide range of variation have more scope for improvement. To identify best combination of parents which result in best hybrids with desirable yield contributing characters, evaluation of the parents and hybrids is done.

\section{MATERIAL AND METHODS}

The study was conducted at the fields of International Crops Research Institute for the Semi-Arid Tropics, Patancheru during kharif 2016-17. The experimental material consisted of 12 parents and 27 hybrids. Hybrids were produced by crossing 12 parents in $\mathrm{L} \times \mathrm{T}$ fashion. Two standard checks were also planted to evaluate the performance of hybrids. These were planted in a Randomized Block Design with three replications. Each genotype is planted at a spacing of $75 \mathrm{~cm} \times 25$ $\mathrm{cm}$ (four rows of four meter length for each genotype). The crop was given two irrigations, one at early vegetative growth and other at pod filling stage. Weeding was done as and when necessary depending upon the intensity of weeds. Observations were recorded on five randomly selected plants for yield and yield contributing characters like Plant height $(\mathrm{cm})$, days to $50 \%$ flowering, days to maturity, number of primary branches per plant, number of secondary branches per plant, number of pods per plant, number of seeds per pod, 100
ISSN: $2320-7051$

seed weight and harvest index $(\%)$. The data was recorded and analysed by standard statistical methods.

\section{RESULTS AND DISCUSSION}

The performance of the pigeonpea in terms of yield and yield contributing characters is presented in the table 1 . In the present study, A lines and $\mathrm{B}$ lines are isogenic differing only for pollen fertility. So, the yield and yield contributing characters have been recorded from B-lines.

Plant height is one of the yield contributing character in pigeonpea because vigour in plant height may increase biomass as well as source-sink capacity, which in turn plays role for optimum yield ${ }^{5}$. The range of plant height was 106.20 to $182 \mathrm{~cm}$ with general mean of $142.85 \mathrm{~cm}$. Among the lines, ICPA $2156(133.67 \mathrm{~cm})$ was very tall. Among the testers ICPL161 $(152 \mathrm{~cm})$ was the tallest tester. Among the crosses, ICPA2039 $\times$ ICPL149 $(182 \mathrm{~cm})$, recorded highest plant height followed by ICPA2039 $\times$ ICPL161 (171 $\mathrm{cm})$. Plant height is influenced by maturity duration, photoperiod and environment. It can be substantially increased by the exposure to long-day conditions ${ }^{4}$.

Early maturing pigeonpea hybrids are generally preferred. It determines the adaptation of the crop to fit into various ecological niches and cropping systems. Delaying in flowering takes place if the temperature during crop growth fluctuates rapidly. The range of days to 50 per cent flowering was 62 to 84 days with general mean of 75 days. Among the lines, ICPA 2156 (67 days) was earliest to flower. Among the testers, ICPL 88039 (62 days) was earliest in flowering. Among the crosses, ICPA $2089 \times$ ICPL88039 (70 days) and ICPA $2156 \times$ ICPL 86022 (70 days) took minimum days to flower. Days to maturity ranged from 105.00 to 135.00 days with general mean 124 days. The line ICPA 2156 (109 days) and the tester ICPL 88039 (105 days) were early to mature among lines and testers respectively. The cross ICPA $2089 \times$ ICPL 86022 (118 days) was earliest 
followed by ICPA $2039 \times$ ICPL 88039 (119 days).

High productivity is said to be closely associated with more number of primary and secondary branches per plant. Number of primary branches per plant ranged from 7.75 to 12.10 with general mean of 10.10 . Maximum number of primary branches per plant was observed in line ICPA2089 (10.63) and tester ICPL88034 (12.10) among the lines and testers. The crosses, ICPA2039 $\times$ ICPL813 (11.97) had relatively maximum number of primary branches per plant followed by ICPA2039 × ICPL90048 (11.27). The range of number of secondary branches per plant was 16.30 to 22.76 with general mean of 19.85 . Among the lines ICPA 2156 (18.87) recorded highest number of secondary branches per plant and among testers ICPL 92047 (21.50) had highest number of secondary branches per plant. Among the crosses, ICPA $2156 \times$ ICPL 88034 (22.77) recorded highest number of secondary branches per plant followed by ICPA 2039 × ICPL 90048 (22.38).

Hybrid vigour and hybrid productivity in pigeonpea is directly contributed by the increase in number of pods per plant. Number of pods per plant ranged from 114.00 to 454.17 with general mean of 214.20. Maximum number of pods per plant was recorded by ICPA 2039 (216.50) among the lines and ICPL 161 (347.73) recorded maximum number of pods per plant among testers. Among the crosses, ICPA $2039 \times$ ICPL 161 (454.17) has recorded highest number of pods per plant followed by ICPA2039 × ICPL90048 (356.53).

Number of seeds per pod and 100 seed weight influence the yield potential. Number of seeds per pod ranged from 3.50 to 4.33 with general mean 3.79. Among the lines, ICPA 2089 (4.33) recorded maximum number of seeds per pod and among the testers ICPL90048 (4.00) recorded maximum number of seeds per pod. Among the crosses, ICPA $2156 \times$ ICPL90048 (4.2) recorded highest number of seeds per pod. 100 seed weight ranged from 7.26 to $9.83 \mathrm{~g}$ with general mean of 8.19 (g). Among the lines ICPA 2039 $(7.97 \mathrm{~g})$ and among testers ICPL88039 (9.83 g) had highest 100 seed weight. In the crosses, ICPA $2156 \times$ ICPL $89(9.07 \mathrm{~g})$ recorded highest test weight followed by ICPA $2039 \times$ ICPL 90048 (9.03 g).

Yield is a complex trait and an end product of many number of components which are under polygenic control. Any change in one or all the components would influence yield $^{5}$. The range of yield per plant was 36.66 to $133.33 \mathrm{~g}$ with general mean of $63.04(\mathrm{~g})$. Out of three lines ICPA 2039 (63.67 g) yielded highest grain per plant while among the testers ICPL 161(100.43 g) recorded highest grain yield per plant. In the crosses, ICPA $2039 \times$ ICPL161 (133.33 g) had highest grain yield per plant followed by ICPA $2039 \times$ ICPL 90048 (116.67 g). This information is depicted in the graph 1.

Partitioning photosynthates into source and sink is indirectly influenced by harvest index. The range of harvest index was 22.05 to $45.34 \%$ with general mean of $34.76 \%$. The line ICPA $2156(36.76 \%)$ had highest harvest index out of the three. Among testers, ICPL161 (41.14\%) recorded highest harvest index. Among the crosses, ICPA 2156 $\times$ ICPL90048 (45.34\%) recorded highest harvest index followed by ICPA $2156 \times$ ICPL92047 (42.63\%).

Table 1: Mean values of parents and hybrids for yield and yield contributing characters.

\begin{tabular}{|c|c|c|c|c|c|c|c|c|c|c|c|}
\hline $\begin{array}{l}\text { Sr. } \\
\text { No }\end{array}$ & Parents/crosses & $\begin{array}{c}\text { Plant } \\
\text { height } \\
(\mathrm{cm})\end{array}$ & $\begin{array}{c}\text { Days to } 50 \\
\text { per cent } \\
\text { flowering }\end{array}$ & $\begin{array}{l}\text { Days to } \\
\text { maturity }\end{array}$ & $\begin{array}{c}\text { No. of } \\
\text { primary } \\
\text { branches } \\
\text { per plant }\end{array}$ & $\begin{array}{c}\text { No. of } \\
\text { secondary } \\
\text { branches } \\
\text { per plant }\end{array}$ & $\begin{array}{c}\text { No. of } \\
\text { pods } \\
\text { per } \\
\text { plant }\end{array}$ & $\begin{array}{c}\text { No. of } \\
\text { seeds } \\
\text { per } \\
\text { pod }\end{array}$ & $\begin{array}{c}100 \\
\text { seed } \\
\text { wt. } \\
(\mathrm{g})\end{array}$ & $\begin{array}{c}\text { Grain } \\
\text { yield } \\
\text { Per } \\
\text { Plant } \\
\text { (g) }\end{array}$ & $\begin{array}{c}\text { Harvest } \\
\text { Index } \\
(\%)\end{array}$ \\
\hline \multicolumn{12}{|c|}{ PARENTS ( FEMALE) } \\
\hline 1 & ICPA 2039 & 106.20 & 77.00 & 125.00 & 9.20 & 16.30 & 216.50 & 3.73 & 7.97 & 63.67 & 34.13 \\
\hline 2 & ICPA 2089 & 131.33 & 68.00 & 113.00 & 10.63 & 18.33 & 118.43 & 4.33 & 7.53 & 37.67 & 23.58 \\
\hline 3 & ICPA 2156 & 133.67 & 67.00 & 109.00 & 10.07 & 18.87 & 114.00 & 3.73 & 7.60 & 36.67 & 36.76 \\
\hline
\end{tabular}




\begin{tabular}{|c|c|c|c|c|c|c|c|c|c|c|c|}
\hline 4 & ICPL 88034 & 134.67 & 83.00 & 132.00 & 12.10 & 18.97 & 183.43 & 3.63 & 8.07 & 54.33 & 33.47 \\
\hline 5 & ICPL 88039 & 131.67 & 62.00 & 105.00 & 10.30 & 19.87 & 198.33 & 3.73 & 9.83 & 70.33 & 29.70 \\
\hline 6 & ICPL 149 & 136.33 & 80.00 & 125.00 & 7.75 & 18.70 & 314.23 & 3.73 & 7.37 & 84.50 & 31.08 \\
\hline 7 & ICPL 161 & 152.00 & 81.00 & 127.00 & 9.80 & 19.27 & 347.73 & 3.73 & 7.93 & 100.43 & 41.14 \\
\hline 8 & ICPL 81-3 & 147.33 & 79.00 & 125.00 & 10.00 & 19.27 & 288.27 & 3.77 & 7.80 & 81.37 & 39.75 \\
\hline 9 & ICPL 89 & 126.20 & 72.00 & 117.00 & 9.67 & 19.43 & 136.90 & 3.67 & 7.80 & 38.67 & 40.18 \\
\hline 10 & ICPL 90048 & 129.67 & 72.00 & 122.00 & 9.07 & 19.67 & 138.93 & 4.00 & 8.63 & 53.00 & 22.06 \\
\hline 11 & ICPL 86022 & 116.67 & 66.00 & 111.00 & 9.23 & 19.31 & 162.33 & 3.77 & 8.07 & 40.00 & 34.81 \\
\hline 12 & ICPL 92047 & 141.00 & 78.00 & 127.00 & 10.40 & 21.50 & 212.73 & 3.73 & 8.27 & 58.33 & 37.12 \\
\hline 13 & $\begin{array}{l}\text { ICPA } 2039 \times \\
\text { ICPL } 88034\end{array}$ & 152.00 & 77.00 & 121.00 & 10.07 & 20.13 & 314.73 & 3.80 & 8.10 & 89.67 & 27.25 \\
\hline 14 & $\begin{array}{l}\text { ICPA } 2039 \times \\
\text { ICPL } 88039\end{array}$ & 144.67 & 73.00 & 119.00 & 10.03 & 22.23 & 203.67 & 3.80 & 8.00 & 63.67 & 34.15 \\
\hline 15 & $\begin{array}{l}\text { ICPA } 2039 \times \\
\text { ICPL } 149\end{array}$ & 182.00 & 84.00 & 135.00 & 10.13 & 19.80 & 352.00 & 3.73 & 8.33 & 102.33 & 35.29 \\
\hline 16. & $\begin{array}{l}\text { ICPA } 2039 \times \\
\text { ICPL } 161\end{array}$ & 171.00 & 83.00 & 132.00 & 10.33 & 21.50 & 454.17 & 3.77 & 8.17 & 133.33 & 34.62 \\
\hline 17. & $\begin{array}{l}\text { ICPA } 2039 \times \\
\text { ICPL } 81-3\end{array}$ & 169.33 & 84.00 & 133.00 & 11.97 & 20.90 & 251.67 & 3.70 & 8.43 & 73.67 & 30.64 \\
\hline 18. & $\begin{array}{l}\text { ICPA } 2039 \times \\
\text { ICPL } 89\end{array}$ & 150.00 & 80.00 & 130.00 & 10.30 & 21.60 & 189.30 & 3.73 & 7.77 & 49.67 & 25.59 \\
\hline 19. & $\begin{array}{l}\text { ICPA } 2039 \times \\
\text { ICPL } 90048\end{array}$ & 145.87 & 83.00 & 134.00 & 11.27 & 22.38 & 356.53 & 3.73 & 9.03 & 116.67 & 31.69 \\
\hline 20. & $\begin{array}{l}\text { ICPA } 2039 \times \\
\text { ICPL } 86022\end{array}$ & 142.00 & 76.00 & 127.00 & 9.85 & 20.20 & 185.87 & 3.80 & 7.83 & 47.83 & 40.67 \\
\hline 21. & $\begin{array}{l}\text { ICPA } 2039 \times \\
\text { ICPL } 92047\end{array}$ & 166.67 & 80.00 & 127.00 & 10.03 & 19.83 & 294.60 & 3.77 & 7.37 & 77.33 & 26.75 \\
\hline 22. & $\begin{array}{l}\text { ICPA } 2089 \times \\
\text { ICPL } 88034\end{array}$ & 139.33 & 72.00 & 121.00 & 9.89 & 20.93 & 222.87 & 3.50 & 8.30 & 63.67 & 31.99 \\
\hline 23. & $\begin{array}{l}\text { ICPA } 2089 \times \\
\text { ICPL } 88039\end{array}$ & 131.20 & 70.00 & 121.00 & 9.76 & 19.98 & 182.33 & 4.13 & 8.10 & 60.00 & 40.68 \\
\hline 24. & $\begin{array}{l}\text { ICPA } 2089 \times \\
\text { ICPL } 149\end{array}$ & 163.33 & 75.00 & 121.00 & 10.02 & 20.27 & 245.33 & 4.00 & 7.40 & 63.00 & 33.98 \\
\hline 25. & $\begin{array}{l}\text { ICPA } 2089 \times \\
\text { ICPL } 161\end{array}$ & 139.33 & 76.00 & 128.00 & 10.01 & 21.83 & 206.12 & 3.77 & 7.27 & 57.00 & 37.31 \\
\hline 26. & $\begin{array}{l}\text { ICPA } 2089 \times \\
\text { ICPL } 81-3\end{array}$ & 146.33 & 74.00 & 123.00 & 10.00 & 21.35 & 243.87 & 3.80 & 8.13 & 74.00 & 35.23 \\
\hline 27. & $\begin{array}{l}\text { ICPA } 2089 \times \\
\text { ICPL } 89\end{array}$ & 129.67 & 73.00 & 122.00 & 10.70 & 20.85 & 166.30 & 3.77 & 8.33 & 54.00 & 43.77 \\
\hline 28. & $\begin{array}{l}\text { ICPA } 2089 \times \\
\text { ICPL } 90048 \\
\end{array}$ & 140.33 & 72.00 & 127.00 & 9.85 & 20.67 & 139.80 & 3.83 & 8.97 & 49.83 & 22.54 \\
\hline 29. & $\begin{array}{l}\text { ICPA } 2089 \times \\
\text { ICPL } 86022\end{array}$ & 136.00 & 72.00 & 118.00 & 10.02 & 18.13 & 123.43 & 3.70 & 8.20 & 37.33 & 34.72 \\
\hline 30. & $\begin{array}{l}\text { ICPA } 2089 \times \\
\text { ICPL } 92047 \\
\end{array}$ & 132.67 & 73.00 & 127.00 & 9.87 & 19.33 & 197.00 & 3.77 & 8.50 & 51.00 & 37.96 \\
\hline 31. & $\begin{array}{l}\text { ICPA } 2156 \times \\
\text { ICPL } 88034\end{array}$ & 151.67 & 75.00 & 125.00 & 10.09 & 22.77 & 160.33 & 3.77 & 8.27 & 46.33 & 27.90 \\
\hline 32. & $\begin{array}{l}\text { ICPA } 2156 \times \\
\text { ICPL } 88039\end{array}$ & 133.33 & 77.00 & 129.00 & 9.82 & 18.23 & 165.93 & 4.00 & 9.00 & 57.00 & 37.97 \\
\hline 33. & $\begin{array}{l}\text { ICPA } 2156 \times \\
\text { ICPL } 149\end{array}$ & 143.00 & 76.00 & 128.00 & 9.76 & 17.17 & 213.53 & 3.73 & 8.03 & 57.00 & 42.09 \\
\hline 34. & $\begin{array}{l}\text { ICPA } 2156 \times \\
\text { ICPL } 161\end{array}$ & 146.00 & 76.00 & 125.00 & 10.57 & 20.37 & 170.07 & 3.73 & 7.67 & 44.67 & 40.35 \\
\hline 35. & $\begin{array}{l}\text { ICPA } 2156 \times \\
\text { ICPL } 81-3\end{array}$ & 151.67 & 76.00 & 124.00 & 10.10 & 19.70 & 161.33 & 3.80 & 8.90 & 52.63 & 39.53 \\
\hline 36. & $\begin{array}{l}\text { ICPA } 2156 \times \\
\text { ICPL } 89\end{array}$ & 134.67 & 71.00 & 123.00 & 10.67 & 19.40 & 150.33 & 3.83 & 9.07 & 47.00 & 23.90 \\
\hline 37. & $\begin{array}{l}\text { ICPA } 2156 \times \\
\text { ICPL } 90048\end{array}$ & 138.00 & 71.00 & 123.00 & 10.87 & 17.07 & 161.63 & 4.20 & 9.00 & 53.33 & 45.34 \\
\hline 38. & $\begin{array}{l}\text { ICPA } 2156 \times \\
\text { ICPL } 86022\end{array}$ & 143.33 & 70.00 & 125.00 & 9.90 & 17.30 & 203.93 & 3.60 & 8.13 & 59.00 & 33.65 \\
\hline 39. & $\begin{array}{l}\text { ICPA } 2156 \times \\
\text { ICPL } 92047\end{array}$ & 149.53 & 72.00 & 123.00 & 9.81 & 19.43 & 205.33 & 3.57 & 7.87 & 58.57 & 42.63 \\
\hline & Parental Mean & 132.22 & 74.00 & 120.00 & 9.85 & 19.12 & 202.65 & 3.8 & 8.07 & 59.91 & 33.64 \\
\hline & Mean of crosses & 147.14 & 76.00 & 126.00 & 10.21 & 20.12 & 219.33 & 3.79 & 8.22 & 64.42 & 33.74 \\
\hline & General Mean & 142.85 & 75.00 & 124.00 & 10.10 & 19.82 & 214.20 & 3.79 & 8.19 & 63.04 & 34.76 \\
\hline & S.Em. \pm & 1.98 & 1.37 & 2.78 & 0.09 & 0.24 & 3.49 & 0.09 & 0.09 & 1.59 & 2.45 \\
\hline & C.D. $5 \%$ & 12.12 & 3.82 & 7.19 & 1.50 & 2.40 & 19.36 & 0.32 & 0.73 & 9.01 & 6.91 \\
\hline & C.V. & 5.22 & 3.13 & 3.57 & 9.15 & 7.45 & 5.56 & 5.20 & 5.48 & 8.79 & 12.22 \\
\hline
\end{tabular}

Note: A lines and B lines are isogenic except for pollen fertility. The observations of yield and yield contributing characters except pollen fertility were recorded on B-lines (ICPB 2039, ICPB 2089 and ICPB 2156). 


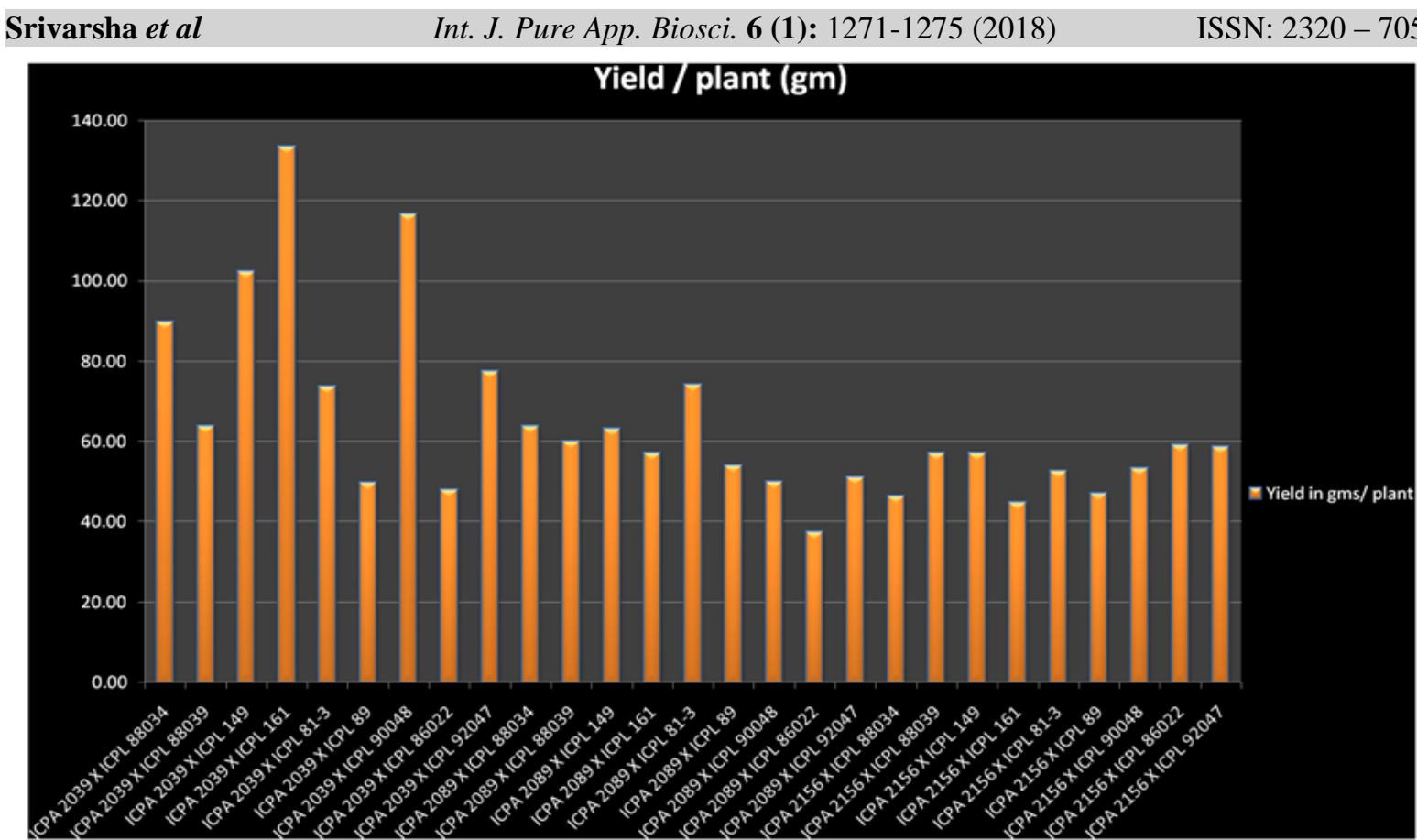

Graph 1: Graph depicting the grain yield/plant (gm) of hybrids

\section{SUMMARY AND CONCLUSION}

The long cherished goal of pigeonpea breeders is to break the yield barrier of the crop ${ }^{7}$. Economic yield is always the preferable trait in almost all the crops. On that basis, ICPA $2039 \times$ ICPL 161, ICPA $2039 \times$ ICPL 90048 and ICPA $2039 \times$ ICPL 149 showed high yield among the experimental material. Further multilocation trails can be carried out and these hybrids can be evaluation in different agro ecologies.

\section{Acknowledgements}

I am thankful to the Agricultural Research Station, Badnapur, VNMKV, Parbhani for giving me the opportunity to work with International Crops Research Institute for Semi-Arid Tropics, Patancheru.

\section{REFERENCES}

1. D. E. S. Directorate of Economics and Statistics, Department of Agriculture and Cooperation. Based on second estimate of 2016-17 (2017).

2. FAOSTAT, http:// faostat.fao.org/ foodstat/collections (2015).

3. IIPR Vision Indian Institute of Pulses Research (ICAR), Kanpur, Uttar Pradesh, India (2030).
4. Kumar, S., Singh, P. K., Kumar, C. V. S., Rajendragouda, P., Sultana, R. and Saxena, K. B. Yield Performance of CGMS based Pigeonpea [Cajanus cajan (L.) Millspaugh] hybrids. Environment and Ecology. 35(1): $73-77$ (2017).

5. Pandey, P., Rajesh, K., Pandey, V. R, Jaiswal, K. K. and Tripathi, M. Studies on heterosis for yield and its component traits on CGMS based pigeonpea [Cajanus cajan (L.) Millsp.] hybrids. Int. J. of Agri. Res. 8: 158-171 (2013).

6. Saxena, K.B., Chauhan, V.S., Johansen, C. and Singh, L., Recent Developments in Hybrid Pigeonpea Research. Proc. Workshop on 'New Frontiers in Pulses Research and Development.'November10 to 12 , 1989, Kanpur, India, pp: 58-69 (1992).

7. Saxena, K. B., Kumar, R. V., Madhavi Latha, K. and Dalvi, V.A. Commercial pigeonpea hybrids are just a few steps away. Indian J. Pulses Res. 19(1): 7-16 (2006).

8. Saxena, K.B., and Nadarajan N. Prospects of Pigeonpea hybrids in Indian Agriculture. Elect. J. Plant Breed. 1: 1107-1117 (2010). 